\author{
Natalia Tokarczyk \\ Łukasz Jarocki \\ Departament Wydarzeń Centralnych ŚDM Kraków 2016
}

\title{
Muzyka Światowych Dni Młodzieży. Raport tuż przed metą
}

Muzyka jako jeden z najważniejszych aspektów życia człowieka ma - przede wszystkim w liturgii - długą i bogatą tradycję, jest także istotną częścią przygotowania najważniejszego wydarzenia we współczesnym Kościele katolickim, którym są ustanowione w 1985 roku przez papieża Jana Pawła II Światowe Dni Młodzieży. W tym roku odbędą się one w Polsce - w Krakowie. Dla sztabu ludzi przygotowujących to przedsięwzięcie poświęcenie należytej uwagi każdemu aspektowi, z których składa się to modlitewne spotkanie młodych z całego świata, wymaga nie lada trudu i czujności oraz dbałości o to, by młodzież mogła jak najpełniej wykorzystać ten czas spotkania z Chrystusem, odkrytym również w drugim człowieku. Nie chcemy przecież, aby w ogromie zadań umknęło nam to, co najważniejsze. Również na nas spoczywa zatem ogromna odpowiedzialność. $Z$ tego powodu do życia powołany został specjalny Zespół ds. Muzyki będący częścią Sekcji Wydarzeń Centralnych Komitetu Organizacyjnego ŚDM. Jego głównym zadaniem jest opracowanie koncepcji muzycznej pięciu głównych wydarzeń, które w lipcu odbędą się na krakowskich Błoniach oraz na Campus Misericordiae w Brzegach k. Wieliczki. Co to oznacza? Zadaniem członków Zespołu jest przede wszystkim wybranie takiego repertuaru oraz przygotowanie zespołów prowadzących (chóru i orkiestry) w taki sposób, aby w tym najważniejszym czasie dla milionów młodych muzyka była pomocą w modlitwie, budowaniu międzynarodowej wspólnoty oraz dawaniu świadectwa wiary w ogóle. Głosem - sercem - życiem.

Chcąc dać szansę na czynny udział w przygotowaniu Światowych Dni Młodzieży jak największemu gronu uzdolnionych osób, w rekrutacji do chóru i orkiestry pod uwagę brane były zgłoszenia z całej Polski oraz świata. Takie założenie sprzyjać miało realizacji wspólnotowego wymiaru ŚDM już na etapie przygotowań, co z pewnością zwiększa szanse na stworzenie atmosfery jedności i bliskości dla milionów pielgrzymów, których gościć będziemy w lipcu.

Od kilku miesięcy (począwszy od października aż do chwili obecnej) trwają przesłuchania, zarówno chórzystów, jak i instrumentalistów, którzy ostatecznie 
zaśpiewają i zagrają podczas głównych uroczystości. Do grona przesłuchujących zaproszeni zostali krakowscy muzycy, dyrygenci oraz pedagodzy, którzy chętnie służąc swoim talentem i kompetencjami, pomogli w skompletowaniu składu chóralnego. W dniach 12-13 marca odbył on swoją pierwszą próbę, a pierwsze spotkania orkiestry planowane są na czerwiec.

Najważniejszą, a jednocześnie wymagającą największej refleksji i uwagi kwestią przygotowań muzycznych jest oczywiście repertuar, który ma zabrzmieć w trakcie Wydarzeń Centralnych. Biorąc pod uwagę fakt, że muzyka podczas tak potężnego zgromadzenia młodych ludzi spełniać powinna kilka ważnych funkcji, na opracowanie koncepcji repertuarowej poświęcono kilka miesięcy. Pamiętajmy o tym, że odpowiednio dobrana muzyka spełnia rolę przede wszystkim wspólnototwórczą, która w kontekście wydarzenia wydaje się najważniejsza. Poprzez śpiew dochodzi bowiem do zawiązania się wyjątkowych więzi pozwalających na wspólną modlitwę. Wybrane pieśni mają za zadanie przekazywać również odpowiednie treści teologiczne, a także wpływają na atmosferę całego wydarzenia. Przy atrakcyjnej różnorodności wydarzeń wpisujących się w to międzynarodowe spotkanie najważniejszym punktem pozostaje oczywiście Eucharystia - zarówno wtorkowa msza otwarcia 26 lipca, jak i kulminacyjna msza posłania, kończąca Światowe Dni Młodzieży w niedzielę, 31 lipca. W jej trakcie zabrzmią między innymi takie utwory jak Deus Caritas est Henryka Jana Botora, Aprite le porte a Cristo Marco Frisiny czy Jesteśmy piękni Piotra Pałki. Nie może zabraknąć również takich pieśni jak Abba, Ojcze i Barka, tak ukochanych przez Jana Pawła II. W dniu 2 kwietnia, w 6. rocznicę Jego śmierci, została opublikowana Missa Ioannis Pauli Secundi-Msza Jana Pawta II skomponowana przez Henryka Jana Botora, i to właśnie ona zabrzmi podczas lipcowej Eucharystii.

Muzyczna propozycja na Światowe Dni Młodzieży w Krakowie ma dodać doniosłości spotkaniu międzynarodowej młodzieży z Chrystusem, a także pomóc w refleksji i modlitwie. Ten cel stale przyświeca organizatorom - dzięki temu jako gospodarze tegorocznego spotkania młodych mamy szansę stworzyć prawdziwie augustiańską zachętę do uwielbiania Boga muzyką i śpiewem, które przenikając całe nasze życie, dodają nam pogody i radości z pogłębiania cudu życia. 